\title{
A crise dos reféns do Irã através da Revista Veja (1979-1981): produção de sentidos através da narrativa jornalística
}

\author{
David Anderson Zanoni ${ }^{\star}$
}

\author{
Palavras-chave: \\ Irã \\ Produção de Sentidos \\ Revista Veja
}

Keywords:

Iran

Production of Meanings

Veja Magazine

\begin{abstract}
Resumo: O presente artigo procura discutir o uso da dinâmica narrativa seriada como elemento de persuasão ao público leitor. Para tanto, analisaram-se os eventos ocorridos em Teerã, capital do Irã entre 1979 e 1981, conhecido como "a crise dos reféns”, reportado pela revista brasileira Veja. Esse episódio insere-se no contexto pós-revolucionário iraniano, o qual proporcionou a ruptura governamental da autocracia do xá (imperador) Mohammed Reza Pahlevi ocasionando a ascensão de uma teocracia islâmica capitaneada pelo Aiatolá (autoridade religiosa islâmica) Rulloah Khomeini. A proposta, portanto, é observar como o periódico transpôs os eventos iranianos levando em consideração sua estratégia narrativa, a dinâmica jornalística utilizada para reportar o Irã no recorte temporal proposto.
\end{abstract}

\begin{abstract}
This article discussesthe use of dynamic serial narrative as persuasive element to the reading public. Therefore, we analyzed the events in Tehran, capital of Iran between 1979 and 1981, known as the "hostagecrisis", reported by the Brazilian magazine Veja. This episode is part of the post-revolutionary Iranian context, which provided the government break the autocracy of theshah (emperor) Mohammed Reza Pahlavi causing the rise of an Islamic theocracy led by the Ayatollah (Islamic religious authority) Rulloah Khomeini. The proposal, therefore, is to see how the news paper translated the Iranian events taking into account their narrative strategy, journalistic dynamics used to report Iran in the proposed time frame.
\end{abstract}

Recebido em 28 de outubro de 2016. Aprovado em 14 de agosto de 2017.

\section{Apresentação}

A imprensa se insere no cotidiano como uma importante ferramenta de informações na contemporaneidade. Os chamados veículos de comunicação de massa, jornais e revistas principalmente, são uma poderosa fonte de divulgação dos eventos ocorridos sobre as mais diferentes ações do homem na sociedade e no mundo moderno. Entretanto, os veículos informativos necessitam constantemente de consumidores (leitores) ávidos por obterem um de seus principais produtos, as notícias.

Levando em consideração as questões mercadológicas, cooptar e manter a atenção de seus potenciais clientes torna-se tarefa imprescindível, pois sem isso a imprensa, como qualquer outra empresa, fica fadada ao fracasso e a não rentabilidade. Isso posto indagamos: que recursos a imprensa utiliza para a manutenção de sua audiência e de seu consumo por parte da população? Dito de outra forma, como os meios de comunicação geram a necessidade de consumo por parte dos leitores?

Uma possível resposta a essas referidas questões é a estratégia verificada através de narrativas traumáticas ou dramáticas. Verificadas normalmente na televisão (novelas, minisséries) e no cinema (filmes - curta e longa metragem), essas narrativas organizam-se em forma de um enredo ou trama e não se esgotam em uma edição. A narrativa segue uma dinâmica cronológica e que vai incorporando novas situações a cada "episódio" (edição); tornando-se, assim, uma saga ou uma contínua série de novas informações a cada novo

\footnotetext{
* Doutorando pelo Programa de Pós-Graduação em História da Universidade de Passo Fundo (UPF). É mestre e graduado em História pela UPF. Atualmente, é Orientador Pedagógico da Secretaria de Educação, Cultura e Desporto da Prefeitura Municipal de Getúlio Vargas/RS.

E-mail: david_zanoni@hotmail.com.
} 
impresso, porém, sem um desfecho preciso. Dessa forma, cria-se, teoricamente, outra necessidade aos leitores: o desejo irresistível de saber o que irá ocorrer no "final da narrativa".

Para tanto, segundo Luiz Gonzaga Motta, os jornalistas empregam uma metodologia denominada lúdico-dramática através de frames (quadros ou molduras). Para o autor:

Osjornalistasutilizamframesnarrativos, porque eles facilitam sua tarefa de enquadrar a complexidade do mundo. Consciente ou inconscientemente, os jornalistas sabem que esses frames dramáticos são rapidamente compreendidos pelos receptores que os utilizam frequentemente no mundo da vida. São, portanto, definidores prévios da situação de comunicação que se vai estabelecer. Frames de recíproca interação através dos quais os interlocutores tornam possível a comunicação jornalística. (MOTTA, 2007, p. 2).

Tal recurso, como já mencionado, é facilmente observado na televisão e o cinema, guardadas, obviamente, suas especificidades. A diferença, pelo que nos parece, está na atribuição feita por parte da imprensa de sua responsabilidade com seu leitor, ou seja, o chamado compromisso com a verdade, a imparcialidade, com os fatos. Sabese, porém, que a lucratividade destes segmentos depende, em suma, da abrangência e capacidade de atrair o público e, assim, manter o consumo deste. Por conseguinte, a imprensa não oficial precisa instrumentalizar-se constantemente para garantir a vendagem de seus exemplares e, acima de tudo, manter suas "portas abertas".

Com relação ao aspecto dramático já citado, este se mostra como uma ferramenta extremamente útil na atração do leitor. Luiz Marfuz (2003, p. 99) explica que "[...] a presença do drama na construção do acontecimento jornalístico é uma das marcas emblemáticas do discurso informativo contemporâneo".

Ao se tratar de processo de narrativa jornalística, Motta (2010 apud Bruner, 2010), explica que essa organização de escrita não se dá por mero acaso, mas, sim, de forma articulada com a proposta de atração do leitor, sendo, inclusive uma condição inerente do ser humano. Nessa perspectiva:

Ao estabelecer sequências de continuidade (ou descontinuidade), as narrativas integram ações no passado, presente e futuro, dotandoas de sequenciação. $\mathrm{O}$ relato temporal perspectiva os estados e as ações em momentos históricos (mudanças evolutivas). Psicólogos culturais afirmam que a nossa tendência para organizar a experiência de forma narrativa é um impulso humano anterior à aquisição da linguagem: temos uma predisposição primitiva e inata para a organização narrativa da realidade (J. Bruner, 1998). (MOTTA, 2010 apud BRUNER, 2010, p. 2).

$\mathrm{O}$ autor reforça, ainda nesta perspectiva que:

Produtos veiculados pela mídia exploram narrativas fáticas, imaginárias ou híbridas procurando ganhar a adesão do leitor, ouvinte ou telespectador, envolvê-lo e provocar certos efeitos de sentido. Exploram o fático para causar o efeito de real (a objetividade) e o fictício para causar efeitos emocionais (subjetividades). Jornalistas, produtores e diretores de TV e cinema, roteiristas e publicitários sabem que os homens e mulheres vivem narrativamente o seu mundo, constroem temporalmente suas experiências. Por isso, exploram com astúcia e profissionalismo o discurso narrativo para causar efeitos de sentido.

A partir dessas considerações iniciais, pretendemos discutir a utilização da narrativa dramática por parte da revista Veja acerca da cobertura do episódio denominado "a crise dos reféns do Irâ” a partir de novembro de 1979. Tal episódio foi intensamente noticiado pela revista e constituiu uma importante fase da história política da, na época, recém-instaurada República Islâmica do Irã, resultado da insurgência popular contra a monarquia do xá Mohammed Reza Pahlevi (1941-1979).

Para tanto, foram escolhidas as seguintes edições da revista Veja: 584 (14 novembro de 1979), 585 (14 de novembro de 1979), 591 (02 de janeiro de 1980), 592 (9 de janeiro de 1980), 608 (30 de abril 
de 1980) e 647 (28 de janeiro de 1981), que compõe o corpus documental desta pesquisa. Nas referidas edições, três delas apresentam os eventos iranianos como reportagem de capa. Além das capas, foram analisados o conteúdo interno, os discursos, as imagens, as entrevistas e um editorial.

Em mais de dois anos de cobertura das movimentações da crise diplomática entre Irã e Estados Unidos, novembro de 1979 a fevereiro de 1981, é importante destacar que cerca de 40 edições da revista abordaram o assunto em questão; contudo, neste estudo, analisamos seis edições que entendemos dar conta da dinâmica aqui proposta, introdução-tensão-resolução.

Portanto, objetiva-se entender como a revista Veja transpôs os eventos decorrentes da tomada da embaixada ao longo dos 444 dias em que se processaram a crise diplomática entre Irã e os Estados Unidos tendo presente o contexto pósrevolucionário iraniano. Levando em consideração o viés ideológico do periódico e seus critérios de noticiabilidade ou valores-notícia, pretendemos entender como o recurso da narrativa dramática e seriada descreveu os acontecimentos da capital iraniana com uma perspectiva de início, meio e fim, ou seja, uma dinâmica narrativa jornalística. Assim, procuramos problematizar a história através da imprensa a partir da observação metodológica de introdução, tensão e resolução proposta pelo periódico ao reportar os eventos oriundos de Teerã em fins da década de 1970.

\section{A introdução: “a tomada da embaixada”}

Como foi salientado no início deste estudo, trataremos das questões aqui apresentadas na perspectiva de uma dinâmica narrativa, comum no meio jornalístico, a qual se estrutura em: introdução, tensão e resolução. A ideia de uma tensão-resolução é aqui entendida a partir de Trombetta, autor que analisa essa dinâmica por meio da música tonal e que também utiliza essa analogia denominando de "tempo-flecha". Segundo o autor:

Na música tonal, além da efetivação de um sistema de composição com regras claras, os jogos de tensão-resolução passam a atravessar todo o tecido musical. Com a presença dos momentos de tensão, a música ganha dinâmica narrativa e incorpora a idéia[sic] de progresso. Tal idéia[sic] encontra na imagem da ciência moderna a o seu impulso mais determinante mais perfeita. (TROMBETTA, 2009, p. 5).

\section{E complementa,}

A fluidez do tempo do progresso, sempre na direção do qualitativamente superior, é representada de maneira bastante explícita na sonata, com uma estrutura constante de três movimentos, governados por um jogo narrativo que "conduz" o ouvinte "movimentando-o" para frente, através de tensões e repousos, na direção de uma resolução final. (TROMBETTA, 2009, p. 5).

Em 4 de novembro de 1979 a embaixada dos Estados Unidos, localizada na capital iraniana Teerã, foi invadida e tomada por estudantes iranianos, os quais mantiveram inicialmente cerca de 60 funcionários da embaixada como reféns. Esse episódio, mais tarde, ficou conhecido como "A crise dos reféns". O fato marcou o rompimento das relações entre Estados Unidos e Irã, que foi restabelecido apenas em 2015 no governo Barack Obama. O episódio se insere no contexto da mudança governamental no Irã, a denominada revolução iraniana, iniciada em 1978 com os protestos populares que reivindicavam a deposição do xá Mohamed Reza Pahlevi e a instauração da República Islâmica do Irã. O antiamericanismo ou "antiocidentalíssimo" ficavam evidenciados nos protestos e nas manifestações populares, o que se inscreve na ação de assalto à embaixada estadunidense.

A embaixada dos Estados Unidos no Irã, um magnífico conjunto de edifícios em meio a um terreno de 11.000 metros quadrados no centro de Teerã, fora ocupada por 400 a 500 estudantes no domingo, dia 4, em seguida a uma gigantesca manifestação em que centenas de milhares de pessoas comemoraram o primeiro aniversário 
da morte de diversos estudantes pelos soldados do deposto xá. (VEJA, 1979a, p. 36).

No recorte citado, reportagem de capa da Edição no 584, a revista trataria de salientar a magnitude do prédio onde ficava a embaixada estadunidense e reforça que a ação dos estudantes iranianos tem a ver também com uma data em especial ligada à violência e morte.

Além dos fatores já referidos que levaram à tomada da embaixada: o ódio declarado aos Estados Unidos e aos valores ocidentais, tidos como deturpadores da fé islâmica, o fato de o governo estadunidense ter exilado o ex-chefe de Estado iraniano, segundo o presidente Jimmy Carter, por questões humanitárias, era elemento definidor da ação dos jovens iranianos.

Em relação às reivindicações dos estudantes, entre várias outras questões, priorizavam a extradição de Mohamed Reza Pahlevi, que havia partido em fuga para os Estados Unidos em janeiro de 1979. Os jovens iranianos objetivavam julgar o xá através das leis do novo regime político. Além disso, os revolucionários exigiam a devolução total dos bens, móveis e imóveis desviados pelo monarca deposto, incluindo depositados em bancos estadunidenses ao longo de mais de três décadas do seu governo.

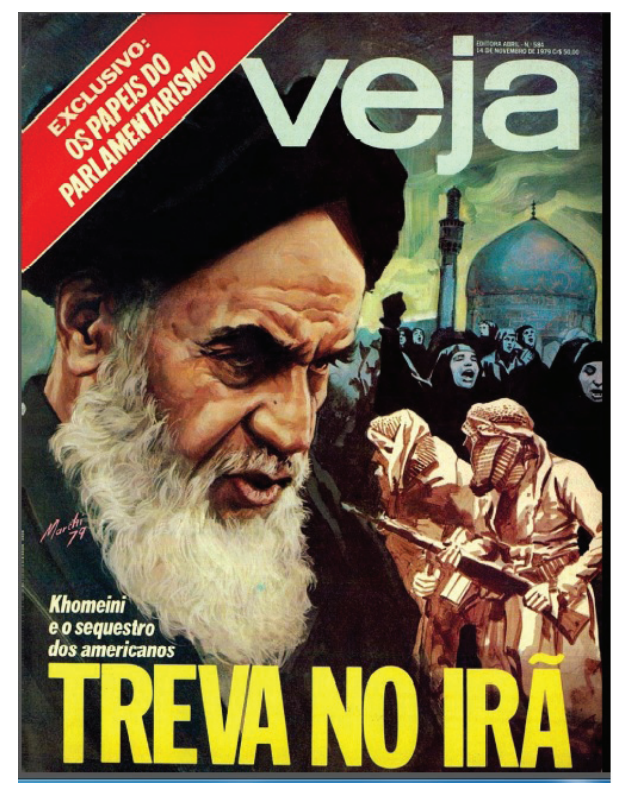

Figura 1 - Capa da revista Veja com o título: Treva no Irã Fonte: Veja (1979a).
A capa da Edição no 584, lançada em 14 de novembro de 1979, demonstrava, entre outros fatores, a participação do Estado iraniano nas ações ligadas à tomada da embaixada. Esta constatação pode ser observada tendo em vista a ênfase dada à imagem do aiatolá Khomeini na capa do semanário. Além disso, a imagem do líder religioso, como de costume, é apresentada com ar agressivo, excêntrico, fechada.

Com o título: “Treva no Irã”, a revista procura dar o tom de drama que parece necessário ao evento, uma vez que se trata de um ato contra os Estados Unidos. No subtítulo "Khomeini e o sequestro dos americanos", percebe-se de que está se tratando de um choque de nações, ou seja, não um fato isolado entre grupos apátridas.

A ideia do sequestro atrelado a um acontecimento dramático mostra-se implicitamente como um mecanismo para apreender o leitor e, nesse sentido, fazer com que, ao ter contato com o evento, identifique-se, vivenciando o ocorrido.

Nas palavras de Luiz Marfuz (2003, p. 104):

No caso do sequestro, acentuam-se estas possibilidades. Há vidas humanas em jogo, conflito e tensão, elementos que, quando enunciados, adquirem o poder de aumentar no telespectador a sensação de estar participando do acontecimento, sugerindo uma coincidência temporal-espacial. Além disso, são inúmeras as possibilidades de identificação entre as personagens envolvidas no acontecimento e o telespectador.

Ainda quanto à referida capa, além da ênfase dada ao aiatolá Khomeini, nota-se, ao fundo, a representação de homens armados e mulheres comemorando tal ação, ou seja, a tomada da embaixada. Uma mesquita, templo religioso da cultura muçulmana, também é apresentada nesta capa. Com relação aos Estados Unidos ou aos funcionários da embaixada, apenas a legenda da conta de lembrar que o evento do sequestro vincula-se a eles, ou seja, temos uma total inclinação ao Irã. Dessa forma, existe, por parte da revista, uma necessidade de enfatizar os sequestradores, demarcar quem são os "bandidos". 
Configurava-se, assim, sem sombra de dúvida, a prática de um ato terrorista pelo estado iraniano - ainda mais que os estudantes ameaçaram matar todos os reféns caso Washington tentasse resgatá-los à força. [...] Desde o início da era Khomeini, a cabeça do xá foi posta, aberta e literalmente, a prêmio. Quem matasse o ex-soberano, decretaram os turbantes iranianos, receberia um prêmio em dinheiro de 350.000 dólares. Mais: qualquer pessoa não iraniana que eliminasse Pahlevi seria acolhida como asilado político no Irã, e condecorado. (VEJA, 1979a, p. 37).

É preciso salientar que essa capa é uma sobreposição de imagens em forma de desenhos ou pinturas e não fotografias; assim, essa edição, em particular, é uma montagem, uma construção iconográfica encomendada. Portanto, demonstra-se artificial tanto na escolha e sobreposição quanto na inexistência das próprias imagens. Trata-se de uma imagem fabricada.

Portanto, articula-se uma clara referência à sociedade iraniana de forma homogênea, que vai do Estado à população, ao que tudo indica, para localizar o leitor de que está se tratando de muçulmanos. Então, o elo entre Estado e população, segundo a revista, é o islamismo; daí a associação. A própria roupa das mulheres, o xador, reforça a mensagem; todavia, é uma maneira de deixar evidente e, digamos, didático, de quem está se falando.

$\mathrm{Na}$ análise do editorial da Edição $n^{\circ} 584$ (Carta ao Leitor), que inaugura o episódio do sequestro, podemos visualizar claramente o posicionamento do semanário quanto aos acontecimentos.

Desde que se transformou em "república islâmica", o Irã vive espasmos de anarquia, introduzida primeiro pelas massas que derrubaram o governo anterior, e, depois, cultivada, desenvolvida e ampliada pelo bando de chefes religiosos que capturou o poder. Ao clima de terror estabelecido no país nos últimos meses, somouse na semana passada um pesadelo a mais: o recurso formal e definitivo, por parte do Estado, a atos de banditismo para a execução de suas políticas. É verdade que já havia sinais disso, quando membros do governo ofereceram prêmios em dinheiro a quem assassinasse o xá deposto. Mas agora, com o seqüestro[sic] da embaixada dos Estados Unidos em Teerã - quando o Irã propõe trocar a vida dos reféns ali aprisionados pela extradição do xá, no momento em um hospital de Nova York -, é o próprio Estado iraniano que, diretamente, oficialmente, assume o crime e o transforma em moeda de câmbio no cenário das nações. No Brasil, ainda há pouco, havia quem falasse com satisfação no "processo iraniano" e festejasse a sapiência revolucionária das "massas do Terceiro Mundo" - não faltando, até mesmo, os que desejassem coisa semelhante para cá. Roga-se, agora, que não sejam renovados tais votos. (VEJA, 1979a, p. 11).

A posição da revista fica notadamente marcada neste editorial. A questão da anarquia - conceito que foge, em sua etimologia, do caos e desordem, apresentados por Veja - é apenas um dos elementos de senso comum enfatizados pelo semanário. $\mathrm{O}$ aspecto religioso é utilizado para marcar um caráter fanático e irracional dos aiatolás, que "capturaram o poder". Para completar temos o caráter dramático, novamente utilizado para noticiar os eventos de Teerã.

Portanto, nada mais dramático que vidas em perigo sendo negociadas, e, além disso, a moeda de troca, o xá Mohammed Reza Pahlevi, estava hospitalizado em tratamento de um câncer nos Estados Unidos. Ao findar deste editorial, a revista trata da opinião no Brasil dos acontecimentos iranianos. Fica explícito que, considerando o contexto brasileiro, a manutenção da ordem trazida pelo golpe de 1964 é o mais interessante, pois não é conveniente, conforme o semanário, que as "massas do terceiro mundo" se revoltem contra a ordem estabelecida pelos Estados.

Em suma, retomando o exposto no início deste artigo, Veja articula a referida notícia com um enredo dramático. Temos um acontecimento, a tomada da embaixada e o sequestro dos funcionários americanos; personagens: os estudantes iranianos, o xá Mohammed Reza Pahlevi e o aiatolá Khomeini e uma sequência de fatos por vir. 


\section{Orientalismo e a sequência dos fatos}

A Figura 2 demonstra vários elementos discutidos ao longo desta pesquisa. Em primeiro lugar, no canto superior esquerdo da foto, temos a ênfase ao antiamericanismo com a mensagem "Down withthe USA". A constante necessidade de Vejareforçar o elemento de raiva e rancor dos iranianos aos Estados Unidos e não explicar devidamente a razão disso parece-nos a tentativa da revista em demonstrar a insanidade dos iranianos e o flagelo estadunidense na situação.

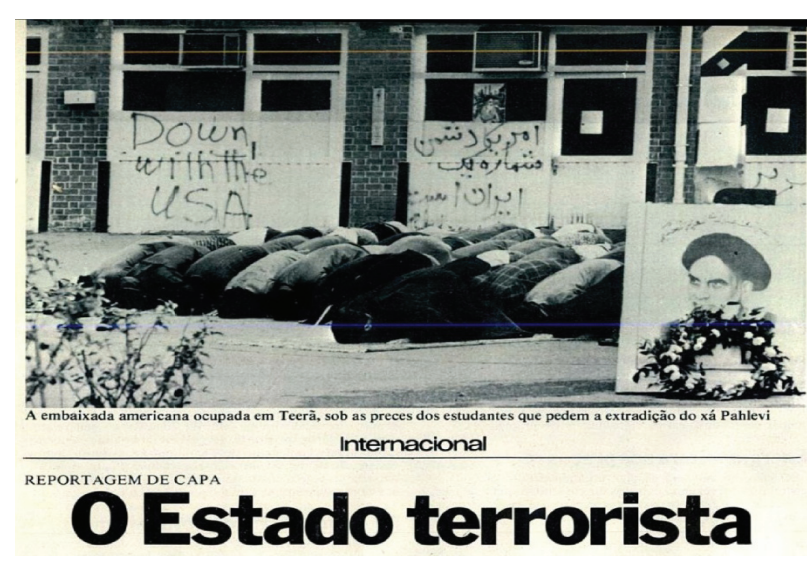

Figura 2 - Iranianos orando em frente à embaixada dos EUA em Teerã

Fonte: Veja (1979a, p. 36).

Em segundo lugar, ao centro da imagem, os militantes que tomaram a embaixada estão cumprindo com um dos pilares do islã, ou seja, a oração. Mais uma vez, a imagem como ilustração do real ou como uma prova indiscutível é utilizada pela revista. Temos novamente a tentativa de impor, através da fotografia, a construção da representação negativa do Irã associada constantemente à religiosidade islâmica. Segundo Kossoy (2009, p. 222-223),

[...] apesar da evolução histórica, a fotografia jornalística continua, perante o senso comum, a passar pelo espelho do real tal como este se apresenta perante a câmera num breve instante, isto é, o que a foto registra "é verdade", aconteceu, e o fotografo esteve lá para o testemunhar.

Demonstrar esse elemento, em um ambiente de violência e ódio, é ligar a religiosidade islâmica ao fanatismo irracional e dito terrorista. Dessa forma, um ato religioso aparentemente comum torna-se um elemento de delírio e inconsciência dos estudantes iranianos. Em terceiro lugar, temos a imagem de Khomeini, no canto inferior direito da foto. O aiatolá aparece como se estive observando os estudantes e vigiando a ação como mentor espiritual e inspirador dos jovens iranianos devotos incondicionalmente ao seu líder supremo. Khomeini constantemente é, nas imagens da revista, representado junto ao ódio, à violência, ao descontrole emocional; enfim, a uma série de elementos negativos e sombrios.

A partir disso, em relação às representações demonstradas, reportamo-nos ao historiador Edward Said (2007, p. 365), que afirma e questiona da seguinte maneira,

[...] o islã tem sido fundamentalmente deturpado no Ocidente -, a questão real é se pode haver uma representação verdadeira de alguma coisa, ou se toda e qualquer representação, por ser representação, não está embutida primeiro na linguagem, e depois na cultura, nas instituições e no ambiente político daquele que representa. Se a última alternativa é correta (como acredito que seja), devemos estar preparados para aceitar o fato de que uma representação está implicada, entretecida, embutida, entrelaçada em muitas outras coisas além da "verdade", que é ela própria uma representação.

Said (2007) discute o fator ideológico presente na representação, uma espécie de discurso hegemônico que é encampado pelo locutor da mensagem, como ele chama "aquele que representa". Esse enunciador é revestido de autoridade e atribui a si a condição de estar trazendo a "verdade" dos fatos, ou seja, sua forma de representar o fato é o real e a ideal ou a mais próxima da verdade. Assim, Vejademonstra o Irã e, juntamente o islã, exclusivamente antiamericano ou antiocidental. Em contrapartida, não visualizamos, nesta edição, uma explicação clara dessa aversão aos Estados Unidos, a não ser o fato de que os iranianos queriam a deportação do ex-monarca iraniano pelos motivos já expostos.

Nas palavras de Said (2007, p. 33-34), 
O orientalismo, portanto, não é uma visionária fantasia europeia sobre o Oriente, mas um corpo elaborado de teoria e prática em que, por muitas gerações, tem-se feito um considerável investimento material. $\mathrm{O}$ investimento continuado criou o Orientalismo como um sistema de conhecimento sobre o Oriente, uma rede aceita para filtrar o Oriente na consciência ocidental, assim como o mesmo investimento multiplicou - na verdade, tornou verdadeiramente produtivas - as afirmações que transitam do Orientalismo para a cultura geral.

Assim, parece-nos ainda mais evidente a construção do outro com a representação da imagem de um Estado que é fundamentado no caos e uma ameaça para o país civilizado e vítima da barbárie. Aspectos da simbologia cultural iraniana como o turbante, por exemplo, são explicitamente ridicularizados pelo semanário. O Estado é chamado de pirata, terrorista e mundo conturbado com base em ideais medievais - uma velha retórica do senso comum em que o medievo foi um período de retrocesso da humanidade - em que reina um bando de chefes religiosos, fanáticos e descontrolados. Assim, cultura, política e religiosidade iraniana são apresentadas como o oposto da razão humana ou do modelo de sociedade civilizada, tendo em vista, obviamente, os padrões ocidentais.

Veja, ao noticiar os eventos sobre a tomada da embaixada, não demonstra preocupação em trazer informações acerca de episódios em que a monarquia figure negativamente. Esse tipo de informação é, praticamente, silenciada ao relatar os eventos iranianos. Algumas páginas depois, Veja limita-se a afirmar que: "[...] Washington ainda achou que poderia aplacar o furioso antiamericanismo dos dirigentes islâmicos, cujas raízes estão no apoio americano à dinastia Pahlevi, durante seus 37 anos de ditadura" (VEJA,1979a, p. 39).

Nesse aspecto, Cogiolla (2008, p. 84) afirma que

[...] a tomada de reféns na embaixada, logo após o ex-xá receber permissão para entrar nos Estados Unidos para tratar um câncer, foi largamente utilizada para manipular a opinião pública norte-americana. A Operação Ajax de 1953 não era conhecida, ou era considerada mais uma das várias invenções oriundas das teorias da conspiração que surgem de tempos em tempos sobre determinado fato. Ao protestarem contra a entrada do xá nos Estados Unidos, os estudantes iranianos temiam uma repetição da Operação Ajax para conduzi-lo novamente ao poder.

Portanto, tal negligência de Vejaaos atos autoritários da monarquia e a participação dos Estados Unidos nestes está relacionada ao perfil imediatista presente no discurso do semanário. O periódico apresenta, aos seus leitores, as notícias acerca do assalto à embaixada estadunidense com um caráter, em primeiro momento, irracional e lunático. Parece-nos que o ódio dos iranianos aos americanos não tem sentido, reforçando um sentimento de antiamericanismo e antiocidentalismo exacerbado e sem critério, transparecendo como uma característica comum de um grupo extremista e de inspiração fanática religiosa, neste caso, islâmica: "[...] o Irã praticou um ato terrorista contra um outro Estado nacional ponto culminante de descontrole de um regime que fuzila em massa seus adversários e está construindo no limiar do século XXI um Estado baseado em princípios medievais" (VEJA, 1979a, p. 38).

Assim, é comum encontramos a relação de atraso cultural, desenvolvimentista ou de progresso falho ligado às ações iranianas. Vinculase seguidamente, através do discurso da revista, a imagem do Irã e de sua sociedade como retrógrados. O semanário utiliza de forma pejorativa o período histórico medieval, julgando-o como um momento de atraso na história mundial. Entretanto, os Estados Unidos, país que estava sendo atingido pela fúria iraniana, procurou, segundo Veja, tomar medidas que não conturbassem o crítico momento político ao qual passava o Irã. Nas palavras da Revista,

Washington vinha sendo tão cauteloso em suas relações com o Irã que mesmo sábias sugestões a respeito da segurança da embaixada em Teerã não foram adotadas para não irritar o regime 
iraniano. Não se construiu uma cerca eletrificada nem se aumentou a altura dos muros da embaixada, mesmo quando o xá foi se tratar em Nova York, recebido pelos EUA por razões humanitárias. (VEJA, 1979a, p. 40).

Assim, entendemos que o Ocidente acredita ter autoridade e propriedade para definir o Oriente, utilizando-se, nas palavras de Said (2007, p. 34), de uma "hegemonia cultural em ação que dá ao Orientalismo a durabilidade e a força necessária [...]" uma "ideia de Europa", "uma noção coletiva que identifica o 'nós' europeus contra 'aqueles' não-europeus[sic] [...] a ideia de uma identidade europeia superior a todos os povos e culturas nãoeuropeus [sic]".

Desse modo, até aqui apresentamos uma síntese dos fatos ocorridos em Teerã a partir da primeira edição que reportou as notícias da tomada da embaixada estadunidense. A questão dramática somada ao aspecto irracional dos estudantes iranianos, apoiados, segundo a revista, pelo Estado, é o elemento central deste primeiro momento. A sequência dos fatos será discutida nas próximas edições.

\section{A tensão: EUA e a tentativa de resgate dos reféns}

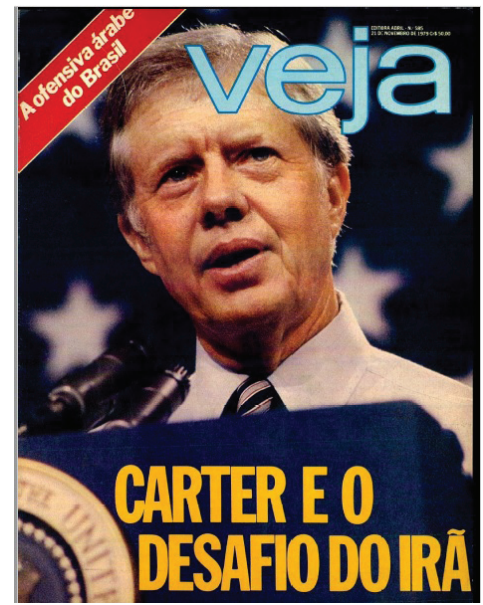

Figura 3 - Capa da revista Veja com o título: Carter e o desafio do Irã Fonte: Veja (1979b).

A Edição no 585, lançada em 21 de novembro de 1979, trazia em sua capa o presidente
Jimmy Carter com um olhar angustiado e, ao mesmo tempo, de incerteza, tendo em vista que estava diante de um embate diplomático longe de uma resolução. Teria ele de encontrar uma saída urgente para a situação dos reféns; contudo, teria igualmente, o chefe de estado estadunidense, de manter o pragmatismo histórico norte-americano, ou seja, não poderia negociar com terroristas. Vejainicialmente ressaltaria o poderio militar dos Estados Unidos, país que teria, segundo o periódico, a capacidade de resolver a situação com "um aperto de botão". No entanto, fraquejavam devido à moderação do presidente, Jimmy Carter, $\mathrm{o}$ qual pretendia encontrar uma solução não belicosa para o caso.

Esta edição enfatiza as exigências dos iranianos, já mencionadas na edição anterior, em uma ideia de localizar o leitor que ainda não havia tomado conta das informações dadas anteriormente. Além das exigências já relatadas abria-se mais um elemento, a possibilidade, levantada pelos iranianos, seria a permissão dos Estados Unidos na entrada de uma comissão para interrogar o xá em solo estadunidense.

Segundo Veja, "o clima do lado iraniano era tão pouco sereno quanto às exigências" $\mathrm{e}$ Jimmy Carter teria sido declarado "inimigo da humanidade" pelo aiatolá Khomeini. Completaria dizendo que "[...] acima de tudo, havia a inquietante possibilidade de que talvez interessasse ao aiatolá e seus turbantes a manutenção da tensão com os EUA por mais tempo [...]" (VEJA, 1979b, p. 40-41).

Tendo em sua mão um complexo militar capaz de varrer do mapa continentes inteiros a um aperto de botão, o presidente continuava, porém, com a mesma limitação drástica da semana anterior de não poder utilizar a força para resgatar os reféns - até pela simples razão de que isso traria enormes problemas para os Estados Unidos. Apesar da enormidade dos meios militares à sua disposição, inclusive próximos do Irã, o presidente acabou tendo de concentrar a maior parte de suas energias no campo da guerra econômica. (VEJA, 1979b, p. 36-37). 
Em um box intitulado "Na embaixada, o centro maior do desvario", Veja atacava ainda mais o Irã enquanto martirizava os reféns e o governo dos Estados Unidos, ou seja, o drama continua.

No harmonioso conjunto da embaixada dos Estados Unidos em Teerã concentrava-se na semana passada o fervor revolucionário da República dos Aiatolás. Ou, como querem os promotores da ocupação da embaixada, ali estava o marco da segunda fase da revolução iraniana - a da "luta antiimperialista”. Isolados em seu interior estavam os personagens centrais desse novo marco do desvario iraniano: cerca de 100 reféns, entre eles 65 americanos, feitos prisioneiros por mais de 400 estudantes muçulmanos. (VEJA, 1979b, p. 40).

Observamos, novamente, que no discurso da revista estão presentes elementos da cultura islâmica, por exemplo, os turbantes, fazendo referência aos apoiadores de Khomeini. Em um tom pejorativo, o periódico emprega o sarcasmo para referendar os iranianos, assim, menosprezando seus hábitos de vestimenta. A característica de enaltecer os Estados Unidos é constante, anteriormente com o complexo militar, agora o próprio conjunto arquitetônico da embaixada.

Por fim, juízos de valor como "desvario" e a "luta anti-imperialista" completam o quadro analítico de Veja e ainda servem para adjetivar o comportamento dos iranianos, passando, constantemente, um ar de irracionalidade e até mesmo de insanidade dos estudantes que, neste acaso inclusive, são chamados de "estudantes muçulmanos", fazendo referência direta com os atos criminosos e a religião professada por eles.

Ainda na Edição n ${ }^{\circ}$ 585, a revista entrevistou o então ministro das relações exteriores do Brasil Ramiro Saraiva Guerreiro. Em um box intitulado "O governo do Irã não deu ordem para a ocupação", Veja interpelou o chanceler brasileiro em busca da opinião do Brasil quanto à "crise dos reféns".

A extrema cautela do Itamaraty em suas reações aos incidentes de Teerã é mais um sinal de que, ante a escalada dos preços do petróleo, não interessa ao Brasil melindrar países produtores - ainda que alguns deles violem de modo flagrante normas que regem a convivência entre nações. É o que demonstra, nesta entrevista a VEJA, o chanceler Ramiro Saraiva Guerreiro. (VEJA, 1979b, p. 45).

Durante a entrevista, o chanceler limitou-se a responder às perguntas de maneira "politicamente correta”, ou seja, sem comprometer-se, sendo coerente com a política de "extrema cautela" do Itamaraty no caso da crise diplomática que envolvia os Estados Unidos e o Irã. Entre as várias perguntas, uma nos chamou mais atenção: "O encarregado de negócios do Irã em Brasília tem feito declarações de apoio aos estudantes...?". O chanceler respondeu: "o governo iraniano não deu ordem para que a embaixada dos Estados Unidos fosse ocupada”.

Observamos um choque de opiniões ou de declarações presentes no periódico. Veja, na edição anterior, chamou o Irã de "Estado-pirata", "Estado celerado", afirmando o engajamento do governo iraniano na ação de assalto à embaixada. Agora, na voz do chanceler brasileiro, temos o contraponto dessa informação. $\mathrm{O}$ que fica evidente, contudo, é que o Brasil, assim como a própria revista, está preocupado na verdade com um elemento apenas, $o$ aumento do combustível devido à crise diplomática estabelecida.

À medida que os dias passavam, as soluções para o impasse diplomático se mostravam mais distantes. Opragmatismo das relações internacionais estadunidenses, o qual "não negocia com terroristas", não abria perspectivas positivas para um resultado satisfatório na disputa pela libertação dos reféns. Assim, Veja explorava em suas abordagens as ações dos Estados Unidos como práticas defensivas, para, acima de tudo, não desagradar os raivosos iranianos. Elemento comum nos discursos da revista é o lado sempre humanitário ligado ao governo norteamericano, transparecendo como um aspecto racional proveniente de uma nação que não oprime, nem prejudica outros Estados.

O germe da impaciência começa a rondar a alma americana. Não é 
de espantar. O natal, tão carregado de simbolismo cristão e esperança fraterna, passou sem que um único dos 49 reféns sequestrados em Teerã há oito semanas por seguidores do aiatolá Ruhollah Khomeini fosse solto. O ex-xá Reza Pahlevi, cuja presença nos Estados Unidos desencadeara o bemorquestrado furor nacional iraniano, até já trocou de refúgio, transferindo para o governo do Panamá as pressões iranianas por sua extradição. (VEJA, 1980a, p. 34).

No entanto, a paciência estadunidense, como descrito por Veja, estava se esgotando. Sobretudo pelo elemento eleitoral, uma vez que o ano de 1980 era marcado pela corrida presidencial entre o atual presidente e seu opositor, governador do estado da Califórnia, Ronald Reagan. O elemento religioso cristão, com o simbolismo do natal, procura trazer um aspecto de paz em tempos de festa. Assim, Veja usa esse subterfúgio discursivo e da simbologia cristã ocidental, a deixando implícita a ideia que nem o natal seria capaz de sensibilizar os iranianos, uma vez que o culto a essa festa no islamismo não tem o mesmo valor que para os cristãos. Assim, subentende-se também que a paz não tem o mesmo valor para islâmicos e cristãos.

Sinal dos tempos, três pastores americanos e um cardeal argelino - não diplomatas profissionais foram admitidos no dia de Natal à embaixada dos Estados Unidos em Teerã. Conversaram com o imã Khomeini, visitaram os reféns, brindaram-nos com ofícios religiosos e, sobretudo, provocaram apreciável alívio entre a população americana. Muito provavelmente contribuíram para afrouxar o emaranhado novelo da crise bem mais do que ao alcance de experimentados diplomatas. Não que estes tenham perdido a competência e o talento, ou que a profissão esteja obsoleta - estariam envelhecendo, isto sim, os pressupostos sobre os quais trabalham. (VEJA, 1980a, p. 35).

"Não confio nesse homem", resmungou o aiatolá Ruhollah Khomeini em sua casa da cidadezinha santa de Qom. De público e por antecipação, ele fulminava assim a missão mediadora do secretário geral da ONU, Kurt Waldheim, esperado dentro de poucos dias em Teerã para tentar resolver a crise entre Irã e EUA. "[...] Waldheim foi tratado como um indesejável". Khomeini definitivamente recusou-se a recebê-lo, deixando o encargo ao ministro do Exterior Sadegh Ghotbzadeh. "As autoridades negaram-se a negociar a questão dos reféns - limitaram-se a declamar unilateralmente seus pontos de vista a respeito" (VEJA, 1980, p. 43).

A diplomacia estadunidense também foi colocada em xeque nesta edição, teria ela perdido seu talento para resolver situações como a "crise dos reféns" do Irã? Na verdade, parece-nos que não, porém os negociadores operavam sobre critérios envelhecidos, talvez pautados por demais na oposição da Guerra Fria. Entretanto, não tardou para os Estados Unidos recorrerem às Nações Unidas para resolver o impasse. A ONU enviou, assim, um representante a Teerã, a fim de discutir um possível acordo ou encontrar um mecanismo para a dissolução da intransigência iraniana. Elemento que seria exposto na Edição no 592, em 9 de janeiro de 1980 .

Nesta edição, portanto, não temos uma resolução apresentada, nem sinal de um desfecho, o que mantém a expectativa dos leitores pelo devir. O elemento de cautela e racionalidade nas ações dos Estados Unidos é um fator salientado por Veja, afirmando que os americanos estão seguindo os manuais diplomáticos. Contudo, o tempo estava passando e Jimmy Carter estava sendo pressionado por setores conservadores da sociedade estadunidense, sobretudo pela cúpula do Partido Republicano, o qual já induzia o presidente, através do Congresso Nacional, a utilizar forças militares na resolução da crise.

\section{A tensão parte 2: o fracasso americano}

Pressionado por setores radicais do governo estadunidense, Carter era compelido a agir de forma mais "enérgica" na situação estabelecida. Desde que assumiu o governo dos Estados Unidos, o presidente era taxado de ser demasiadamente 
moderado em situações críticas e que, na visão de políticos mais conservadores, exigia um pulso mais firme na tomada de decisões. Assim, em abril de 1980, Carter aprovaria uma ação militar secreta, de resgate aos reféns no Irã. A operação "Blue Light" foi colocada em prática no dia 28 de abril daquele ano, contando com o que havia de mais moderno em termos de recursos militares. É importante destacar que este era o último ano de mandato de Jimmy Carter na presidência do país e que ele tentava a reeleição.

A resolução da "crise dos reféns" poderia significar a manutenção de seu governo ou a derrocada total. Mesmo com a ameaça dos estudantes de "justiçar" os reféns em caso de tentativa de resgate militar, Carter resolveu aderir às vozes dos conselheiros que consideravam essa estratégia a mais correta, tendo em vista a falha nas tratativas de resolução da crise, de forma não belicosa até aquele momento.

A ousadíssima operação Blue Light, ou Luz Azul, que na noite da última sexta-feira deveria culminar com o resgate dos cinquenta cidadãos americanos sequestrados há 175 dias na embaixada dos Estados Unidos em Teerã, terminou tragicamente, com um dos maiores fracassos já vividos pela nação americana em sua história de armas. [...] Logo cedo, às 7 horas da manhã, o próprio presidente Carter se apresentara em cadeia nacional de televisão para comunicar o desastre e assumir plena responsabilidade pela operação abortada. (VEJA, 1980, p. 30).

Veja procurou explorar o episódio de várias formas. Apresentou os fatos como um fiasco e igualmente como uma tragédia. Em um infográfico, intitulado "etapas do fiasco", a revista demonstrou os planos de resgate que se mostraram falhos e que, ao fim, ainda trariam um saldo negativo de oito soldados americanos mortos. Outro elemento que não podemos deixar de destacar em relação à crise é a corrida presidencial nos Estados Unidos. Ronald Reagan, então governador do estado da Califórnia e candidato à presidência, explorou a crise a seu favor, o qual teria, mais tarde, agido decisivamente no assunto.
O aspecto trágico ao evento, como citado, teve um ar de humanização, ao mesmo tempo em que tentava explicar o inexplicável, ou seja, como uma operação dessa magnitude fora acabar em uma "trapalhada" e, além disso, causara primeiro a morte de cidadãos americanos e, segundo, a perda de valiosos recursos militares. Ainda mais, sem contar outro fator de extrema relevância, provocar os estudantes iranianos que já haviam demonstrado sua intolerância caso ocorresse esse tipo de situação. Além de tudo, Carter colocou em risco a vida dos reféns americanos em prol de sua campanha eleitoral.

Neste episódio, as perdas e danos aos
Estados Unidos da América, maior
potência mundial, vão bem além do
que restou abandonado no deserto
iraniano - além dos soldados mortos,
lá ficaram sete helicópteros Sikorski
RH-53 que custam quase 1 milhão de
dólares cada, uma avião de transporte
Hércules C-130 (6 milhões de dólares),
além do próprio plano de como seria
executada a tomada da embaixada
dos Estados Unidos em Teerã. Lá
ficaram abandonados, sobretudo, a
honra militar dos Estados Unidos,
a capacidade de julgamento de seu
atual presidente e a confiabilidade
da própria superpotência americana.
(VEJA, 1980, p. 30).

Não tardou para críticas de todo o mundo serem expressas contra a ação estadunidense. Jornais de países europeus e militares da OTAN se pronunciaram sobre o evento, e Veja explorou igualmente esses argumentos. No entanto, o periódico não deixava de demonstrar dois elementos-chave: a união dos americanos, mesmo sendo opositores políticos, em relação à situação dos reféns e, da mesma forma, a melhor maneira de resolução para a crise, seguido da preocupação de Carter com a campanha eleitoral que se mostrava cada vez mais decisiva, principalmente após o desfecho da operação "Blue Light". Parece, à luz das análises, que Veja procurou demonstrar a fraqueza de Carter reforçando a imagem de um presidente incompetente para o cargo e posição de estadista da maior potência ocidental. 
Só que Jimmy Carter é um presidente sitiado por problemas, por falta de confiança, e por uma eleição cada vez mais ameaçadora. Por enquanto, nesses primeiros dias após a catástrofe da operação Blue Light, prevaleceu o clima de união nacional até mesmo entre combatentes políticos. [...] Poucas vezes, em sua história contemporânea, o país terá se sentido tão por baixo - e esses sentimentos de frustração, somados a inconsistências de Carter no trato da questão iraniana durante os últimos seis meses, bem poderão representar um golpe definitivo no futuro de seu presidente. (VEJA, 1980, p. 36).

É importante lembrar que Veja fala em fracasso e denomina como catástrofe dos Estados Unidos ao se referir a tentativa de resgate em abril de 1980, mas não rememora, por exemplo, fracassos anteriores e próximos, como o caso do Vietnã na década de 1970. A questão vietnamita ainda era latente na memória coletiva estadunidense, questão não cotejada por Veja. Derrotas como essa ficaram como marca indelével na cultura estadunidense, daí a questão se tornar ainda mais representativa.

\section{A resolução: a posse de Ronald Reagan e a libertação dos reféns}

A Edição no 647, do dia 28 de janeiro de 1981, trazia em sua capa o retorno dos reféns americanos após os 444 dias que ficaram detidos sob o controle dos estudantes iranianos na embaixada estadunidense em Teerã. Terminava, assim, a "crise dos reféns" iniciada em novembro de 1979. Na capa, além da imagem de alguns reféns descendo do avião e acenando com a expressão de felicidade, estava logo abaixo Ronald Reagan e sua esposa com imagem de fogos de artifício para uma dupla comemoração: a resolução positiva da crise diplomática e a vitória nas urnas de Reagan. O título da capa era sugestivo:"A festa americana".

Durante toda essa edição, ressaltouse principalmente $o$ aspecto dramático que foi o episódio do sequestro; além disso, o orgulho estadunidense ferido também foi largamente destacado. A pecha que ficaria sobre a imagem da diplomacia internacional com o ato dos estudantes iranianos ao atacar um órgão diplomático, o qual serve para dialogar com nações, ou seja, atacouse um centro de negociações da maior potência mundial. Esse tom vitimizante que o discurso de Veja apresenta ou representa os Estados Unidos é constante na edição do dia 28 de janeiro de 1981.

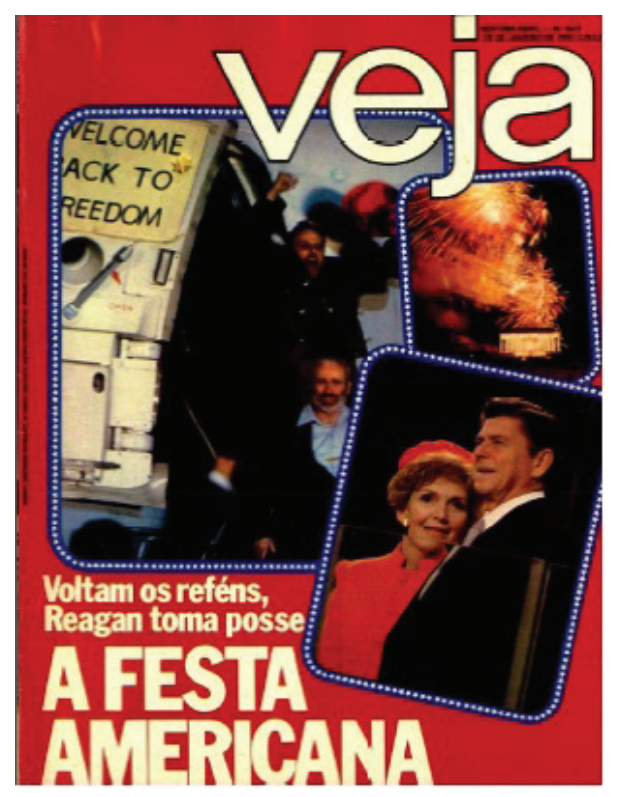

Figura 4 - Capa da revista Veja com o título: A festa americana

Fonte: Fonte: Veja (1981).

Não será fácil deixar de ser refém. Nem para os 50 homens e suas mulheres que viveram isolados do mundo, durante mais de 14 meses, sequestrados pelo furor revolucionário que tomou conta do Irã, nem para os Estados Unidos, que viveram 444 dias com sua história sendo pisoteada e ferida, vulneráveis a exigências disparadas, em absoluto desprezo de qualquer lei, pelas conflitantes autoridades de Teerã.

Só muito lentamente as partes envolvidas nesse drama sem precedentes conseguirão encontrar suas identidades e reassumir o papel que ocupavam até a manhã do dia 4 de novembro de 1979, um domingo, quando se deu o sequestro. (VEJA, 1981, p. 28).

A posse de Reagan culminando com a libertação dos reféns também é largamente explorada nesta edição. A chegada ao poder do $40^{\circ}$ presidente norte-americano foi emblemática. Digna 
de um enredo hollywoodiano, o que não seria totalmente deslocado, levando em consideração o fato de que ele foi ator de filmes de Hollywood.

Muitos comentaristas apontam a trapalhada militar de Carter como principal causa de sua derrota nas eleições seguintes (1980) ganhas por Ronald Reagan. Documentários televisivos revelam, de fato, que houve uma negociação secreta entre Ronald Reagan e o Irã para alongar a crise até as eleições. Pouco depois de Reagan ser eleito o problema foi "milagrosamente" resolvido. Em janeiro de 1981, após 444 dias de cativeiro, os reféns da embaixada norte-americana foram libertados por gestões diplomáticas da Argélia. Os recursos do Irã depositados em bancos ocidentais foram liberados, a vitória do Irã foi total. Os 23 bilhões de dólares, congelados em bancos norteamericanos, foram devolvidos ao país. Os reféns voltaram aos Estados Unidos, Reagan marcou pontos na agenda internacional e o Irã recebeu uma compensação em forma de armamentos (vendidos clandestinamente pelos Estados Unidos como veremos). (COGIOLLA, 2008, p. 85).

Paralisada pela sucessão de sobressaltos que marcou essa longa agonia, a nação americana, assim como os reféns do avião, esparramou emoção, patriotismo e frustrações contidas ao saber, na última terça-feira, que o pesadelo finalmente acabara. Era justamente o dia da posse do $40^{\circ}$ presidente dos Estados Unidos, Ronald Reagan.

[...] Reagan teve o privilégio de anunciar, exatos 27 minutos após tomar posse, que os reféns haviam sido soltos, iniciando seu governo com uma espetacular explosão de alívio nacional, e livre, sem ter tido nenhum trabalho, do problema que envenenou até o fim o mandato de seu antecessor Jimmy Carter. (VEJA, 1981, p. 28).

Assim se sucede nas páginas seguintes da Edição $n^{\circ}$ 647, com a exaltação da libertação dos reféns, a chegada ao poder de Reagan e a análise na condição de vítima atrelada aos Estados Unidos frente o Irã (VEJA, 1981). Entretanto, em momento algum, temos a análise dos motivos que teriam levado os iranianos a assaltar a embaixada e manter os reféns por 444 dias. Também é ocultada ou simplesmente não proposta a reflexão da concomitância da libertação dos reféns com a vitória de Reagan ao poder. A exposição é superficial porque supostamente é a verdade e a verdade está acima de questionamentos. Assim, quando é utilizado esse discurso, este não tem a preocupação em trazer um aspecto crítico ou reflexivo, mas apenas a exaltação da vitória do novo presidente e de uma nova era que iniciava sem o espectro dos iranianos com os reféns estadunidenses.

\section{Considerações finais}

Primeiramente, temos de destacar a ideia da transposição dos fatos por meio da dinâmica narrativa seriada. Nas edições analisadas, existem elementos que dão conta de estabelecer uma sequência de notícias dos eventos iranianos. Essa articulação jornalística não é despretensiosa, pelo contrário, é justamente uma estratégia para manutenção da audiência dos leitores do periódico.

Pode-se observar que no discurso, tanto escrito quanto imagético, Veja apresenta o Irã como um Estado terrorista e que violava as mais comuns normas de convivência internacional. O Irã cometeu, segundo o periódico, um ato de banditismo contra uma nação pacífica e ordeira, configurando-se, assim, como um "Estado pirata".

As imagens das edições analisadas apresentam um país de fanáticos religiosos, violência, caos e desordem generalizada. Isso tudo motivado pelo ingresso dos religiosos ao poder como resultado da revolução iraniana de 1979. Quando os Estados Unidos são apresentados, as imagens traduzem um país que sofria pela ação descabida e irracional dos "turbantes" iranianos, ou simplesmente "tresloucado e enraivecido poder dos aiatolás".

Tanto para o Irã quanto para os Estados Unidos, as escolhas das imagens procuram deixar claro, aos leitores, quais características representam cada Estado. Com a ação de resgate dos reféns, o episódio que se torna um "fiasco", como a 
própria revista denomina, é carregado de um panorama heroico, que acabou em uma trapalhada inimaginável. A comoção dos americanos com a frustrada tentativa de resgate é demonstrada e apresenta-se, também, a crítica na hesitação de Carter em agir para resolução mais incisiva na crise que se estendia. Neste aspecto, temos o caráter dramático que circunscreve toda a seriação disposta dos fatos reportados.

O patrocínio dos Estados Unidos ao governo de Mohamed Reza Pahlevi, após a operação Ajax (1953-1979), proporcionou a formação de um governo autocrático, ditatorial e que promovia uma sumária perseguição aos adversários políticos. Além disso, tal processo repressivo atentava contra a religiosidade islâmica, o que também não é discutido por Veja. A compra de armas pelo governo iraniano monárquico em detrimento de uma população que vivia marginalizada e em condições de miserabilidade intensa, sem saneamento básico, saúde e educação, também não é aprofundada pelo periódico.

O episódio dos reféns é mais um exemplo de como Veja articulou sua midiatização posicionada contra o islã e os iranianos. A revista não poupou os adjetivos e substantivos que demonizassem o Irã e enaltecessem ou vitimassem os Estados Unidos. Termos como tresloucado, raivoso, delirante são comuns para referendar os iranianos, principalmente em se tratando dos religiosos. Constrói-se uma imagem do Irã e sua sociedade ligada ao caos e à irracionalidade; ao estabelecer essa imagem, reforça-se o lado racional e o modelo a ser seguido, ou seja, o ocidental, o qual é progressivo e civilizado. Dessa forma, ao representar o Irã e o Islã, Veja estabelece a imagem positiva do Ocidente legitimando um paradigma de sociedade ideal em franca oposição ao polo negativo, o Oriente.

\section{Referências}

COGIOLlA, O. A Revolução Iraniana. São Paulo: Ed. da Unesp, 2008.

KOSSOY, B. Realidades e Fiç̧ões na trama fotográfica. 4. ed. São Paulo: Ateliê, 2009.
MARFUZ, L. A dramatização da notícia: a construção do personagem Pareja nos telejornais. In: VALVERDE, M. (Org.). As formas do sentido: estudos em estética da comunicação. Rio de Janeiro: DP\&A, 2003. p. 99-120.

MOTTA, L. G. Jogos de linguagem e efeitos de sentido da comunicação jornalística. Estudos em jornalismo e Mídia, Florianópolis, v. 1, n. 2, p. 117-133, 2010.

Enquadramentos lúdicodramáticos no jornalismo: Mapas Culturais para organizar conflitos políticos. Intexto, Porto Alegre, v. 2, n. 17, p. 1-25, 2007.

TROMBETTA, G. L. Tensão e resolução: a dinâmica sonora e o espírito da modernidade. In: SIMPÓSIO NACIONAL DE HISTÓRIA, 25., 2009, Fortaleza. Anais... Fortaleza: UFCE, 2009. p.1-8.

SAID, E. W. Orientalismo: o Oriente como invenção do Ocidente. Tradução de Rosaura Eichenberg. São Paulo: Companhia das Letras, 2007.

VEJA. Abril Acounts- Acervo digital da Revista Veja. Disponível em: $<$ https://acervo.veja.abril.com. br/index.html>.Acesso em: 7 ago. 2016.

Edição no 584, 14 nov. 1979a, p. 36.Abril

Acounts - Acervo digital da Revista Veja Disponível em: <https://acervo.veja.abril.com.br/index.html>. Acesso em: 7 ago. 2016.

Edição no 585, 21 nov. 1979b, p. 36-37. Abril Acounts - Acervo digital da Revista Veja. Disponível em: <https://acervo.veja.abril.com.br/ index.html>. Acesso em: 7 ago. 2016.

Edição no 591, 2 de janeiro de 1980a, p. 34-35. Abril Acounts - Acervo digital da Revista Veja. Disponível em: <https://acervo.veja.abril.com. br/index.html>. Acesso em: 7 ago. 2016.

Edição $\mathrm{n}^{\circ}$ 592, 9 de janeiro de 1980b, p. 43. Abril Acounts - Acervo digital da Revista Veja. Disponível em: <https://acervo.veja.abril.com. br/index.html>. Acesso em: 7 ago. 2016. 
Edição nº 608,30 de abril de 1980, p. 3036. Abril Acounts - Acervo digital da Revista. Veja Disponível em: <https://acervo.veja.abril.com.br/ index.html>. Acesso em: 7 ago. 2016.
Edição n 647, 28 jan. 1981, p. 28-34. Abril Acounts - Acervo digital da Revista Veja.Disponível em: <https://acervo.veja.abril.com.br/index.html>. Acesso em: 7 ago. 2016. 